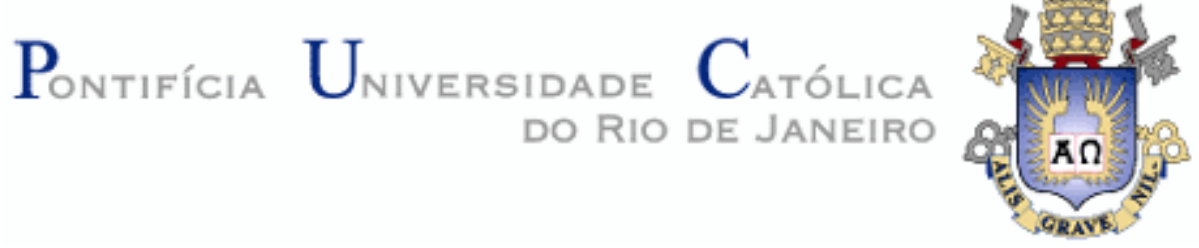

Isabel Cristina Fernandes Auler

\title{
Autobiografia e a tênue fronteira entre os gêneros narrativos
}

Tese apresentada como requisito parcial para obtenção do grau de Doutor pelo Programa de Pós-Graduação em História Social da Cultura do Departamento de História do Centro de Ciências Sociais da PUC-Rio.

Orientador: Prof. Luiz de França Costa Lima Filho 


\section{Isabel Cristina Fernandes Auler}

\section{Autobiografia e a tênue fronteira entre os gêneros narrativos}

Tese apresentada como requisito parcial para obtenção do grau de Doutor pelo Programa de Pós-Graduação em História Social da Cultura do Departamento de História do Centro de Ciências Sociais da PUC-Rio.

Aprovada pela Comissão Examinadora abaixo assinada.

Prof. Luiz de França Costa Lima Filho Orientador Departamento de História - PUC-Rio

Prof. Maurício Barreto Alvarez Parada Departamento de História - PUC-Rio

Prof. Henrique Estrada Rodrigues Departamento de História - PUC-Rio

Prof. Felipe Charbel Teixeira Instituto de História - UFRJ

Prof ${ }^{a}$ Ana Lúcia Machado de Oliveira Instituto de Letras - UERJ

Profa. Mônica Herz

Vice-Decana de Pós-Graduação do Centro de Ciências Sociais

PUC-Rio

Rio de Janeiro, 02 de setembro de 2015 
Todos os direitos reservados. É proibida a reprodução total ou parcial do trabalho sem autorização do autor, do orientador e da universidade.

\section{Isabel Cristina Fernandes Auler}

Graduou-se em História pela Pontifícia Universidade Católica do Rio de Janeiro em 2008. Tornou-se Mestre em Historia pela Pontifícia Universidade Católica em abril de 2011.

Ficha Catalográfica

Auler, Isabel Cristina Fernandes

Autobiografia e a tênue fronteira entre os gêneros narrativos / Isabel Cristina Fernandes Auler ; orientador: Luiz de França Costa Lima Filho - 2015.

$165 \mathrm{f.} ; 30 \mathrm{~cm}$

Tese (doutorado)-Pontifícia Universidade Católica do Rio de Janeiro, Departamento de História, 2015.

1. História - Teses. 2. Autobiografia. 3. História. 4. Ficção. 5. Mímesis. I. Lima Filho, Luiz de França Costa. II. Pontifícia Universidade Católica do Rio de Janeiro. Departamento de História. III. Título. 


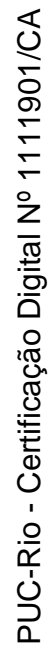

Ao meu marido e a minha mãe,

Por todo amor, carinho e apoio.

Amo muito vocês! 


\section{Agradecimentos}

Ao meu orientador, Prof. Luiz Costa Lima, por todo carinho e apoio na realização deste trabalho. Você é um amigo muito querido e uma grande inspiração!

A CAPES e à PUC-Rio, pelo auxílio que tornou a realização deste trabalho possível.

Aos professores e funcionários do departamento, pelos ensinamentos e pelo carinho. Especialmente ao Cláudio, com quem tive o enorme prazer de trabalhar durante o ano de 2010! Sinto muitas saudades!

Aos meus amigos da PUC, em especial à minha querida amiga Daniela Yunnes!

Aos meus familiares, em especial à minha mãe e ao meu marido, por toda compreensão e confiança. Não conseguiria realizar este trabalho sem o amor e apoio de vocês dois! 


\section{Resumo}

Auler, Isabel Cristina Fernandes; Filho, Luiz de França Costa Lima. Autobiografia e a tênue fronteira entre os gêneros narrativos. Rio de Janeiro, 2015, 165 p. Tese de Doutorado - Departamento de História, Pontifícia Universidade Católica do Rio de janeiro.

O principal objetivo de minha tese reside na análise das peculiaridades do gênero autobiográfico, o qual possui um compromisso com a constituição (mesmo que inconsciente) de um projeto identitário. Apesar da aparente fidelidade a "verdade do ocorrido", própria da escrita historiográfica, a evocação do autor desloca sua narrativa mimética do campo da reprodução para o campo da produção, sem, no entanto, transgredir o real, ato realizado pela narrativa ficcional. Apesar de não postular limites categóricos entre estes gêneros narrativos, e, pelo contrário, defender a possibilidade de um constante diálogo entre eles, acredito que a interlocução não apague as fronteiras existentes entre os diferentes discursos. Esta tênue diferença consiste na capacidade do autor em manter seu compromisso aporético durante o ato criação, a manutenção, portanto, da hierarquia das intenções no momento da escrita. Para identificar tal diferença, cabe ao leitor ser capaz de engendrar em sua análise um mínimo de interseção entre seu repertório, ou seja, o conjunto de normas sociais inerentes ao leitor e, consequentemente, à sua recepção da obra, e o repertório do texto, a hierarquia das intenções presente no processo de produção dos discursos.

\section{Palavras-Chave}

Autobiografia; História; Ficção; Mímesis. 


\section{Abstract}

Auler, Isabel Cristina Fernandes; Filho, Luiz de França Costa Lima. (Advisor) Autobiography and tenuous border between the narrative genres. Rio de Janeiro, 2015, 165 p. PhD. Thesis - Departamento de História, Universidade Católica do Rio de Janeiro.

The main objective of my thesis is the analysis of the peculiarities of the autobiographical genre, which has a commitment to the configuration of an identity project. Despite the apparent commitment with the "truth", which is proper of the historiographic genre, the act of recollection shifts the Mimetic narrative of the field of reproduction to the field of creation, without transgressing reality, act performed by the fictional narrative. The author doesn't defend categorical boundaries between these genres, on the contrary, defends the possibility of a constant dialogue among them, even though, these dialogues do not delete the existing border between the different speeches. The subtle difference between genres resides on the ability of the author to keep your commitment during the act of creation, his ability to maintain the hierarchy of intentions during his writing. To identify such a difference, it is up to the reader to be able to engender in his analysis a connection between his repertoire- social conventions that orients his reading - and the text repertoire, which means the hierarchy of intentions that is present during the production of the speech.

\section{Keywords}

Autobiography; History; Fiction; Mimesis. 


\section{Sumário}

1. Introdução 10

1.1. A tênue fronteira entre os gêneros narrativos 10

2. O gênero ficcional 16

2.1. A liberdade do imaginário e a transgressão do real 16

3. O gênero historiográfico 66

3.1. A incansável busca pela "verdade" do ocorrido 66

4. O gênero autobiográfico 89

4.1. Reflexões sobre si 89

5. O Amante de Marguerite Duras 132

5.1. Uma autobiografia em preto 132

6. Conclusão 154

6.1. Hierarquia das intenções 154

$\begin{array}{ll}\text { Referências bibliográficas } & 161\end{array}$ 
A maior riqueza do homem é a sua incompletude. Nesse ponto sou abastado. Palavras que me aceitam como sou - eu não aceito.

Manoel de Barros, Retrato do artista quando coisa. 